\title{
Relationship between Poverty and Socio- demographic Characteristics of Poor Households: A Case Study in Kelantan, Malaysia
}

\author{
Chamhuri Siwar, Ferdoushi Ahmed and Nor Diana Mohd. Idris \\ Institute for Environment and Development (LESTARI) \\ Universiti Kebangsaan Malaysia, 43600 UKM, Bangi, Selangor D.E., \\ Malaysia.
}

\begin{abstract}
Poverty is a complex and comprehensive phenomenon and covers many dimensions of human and social behaviour. Therefore, poverty reduction has become the most important issue in the development policies of almost all the countries including Malaysia. Poverty in Malaysia has generally been perceived as a rural problem since poverty is much higher in rural areas of the country. This study aims to identify the socio-demographic factors that affect the levels of poverty among the households in Kelantan, Malaysia. The paper also focuses on various aspect of household poverty in Kelantan state of Malaysia. The data for this study were obtained from the Implementation and Coordination Unit (ICU), Malaysia which collected the information through household survey in the 65 sub-districts under 10 districts in the Kelantan state of Malaysia. The data were descriptively analyzed utilizing the socio-demographic profiling approach. The surveyed households were divided into four poverty groups: poorest, poor, vulnerable and out of poor. Findings of the study show that proportion of the poor households in rural areas is higher $(39.11 \%)$ than that of urban poor $(30.15 \%)$. In contrast, a greater portion of the urban households $(52.80 \%)$ are vulnerable to poverty compared to the
\end{abstract}

rural households $(35.98 \%)$ of the state. Analysis also reveals that the lowest portion (on average, $4.5 \%$ ) of the household's heads in each education level are the poorest while the greatest portion (on average, $48 \%$ ) of them are vulnerable to poverty. Majority of the families from each poverty group live in a very poor or poor housing condition. Therefore, further research on identification of poverty groups and socio-economic characteristics of such groups is urgently needed for more effective policies and approaches to reduce the rate of poverty in the country. Key words: Poverty, Socio-demographic characteristics, Households, Kelantan, Malaysia.

\section{INTRODUCTION}

Poverty is a persisting problem not only in under-developed and developing countries but also in developed countries around the world. It is a complex and comprehensive phenomenon and covers many dimensions of human and social behavior. In the today's modern world, the concept of poverty is explained in various ways.World Bank defines poverty as lack of food, shelter, access to healthcare services, basic education, employment opportunity, clean water and social exclusion (World Bank, 2005). The study also reported that individuals whose consumption or income level falls below 
the minimum level of human basic needs are considered as poor. Jiun and Nga (2011) opines that people in poverty cannot afford their basic needs such as safe drinking water, nutrition, healthcare, education, clothing and shelter as a result of persistent lack of income. In fact, poverty has numerous manifestations which include hunger and malnutrition, ill health, lack of income and productive resources to ensure sustainable livelihood, limited or lack of access to education and other basic services, increased morbidity and mortality from illness, homelessness and inadequate, unsafe and degraded environment and social discrimination and exclusion (Ijaiya, et al. 2011). It is also characterized by lack of participation in decision making in civil, social and cultural life (World Bank, 1990; United Nations, 1995). Therefore, poverty reduction has become the most important issue in the development policies of almost all the countries in the world.

Poverty alleviation is one of the main objectives of the development policy in Malaysia (Roslan, 2004). Poverty in Malaysia is defined as having insufficient income to purchase a minimum basket of food to maintain household members in good health and do not have access to other basic needs such as health care, education, house rental and clothing (Malaysian Quality of Life 2002). The Malaysian economy experienced rapid growth and structural changes during the last three decades (Mat, et al. 2011). At the same time, there was a large reduction in the incidence of poverty in the country. In the early 1970's almost half of the households $(49.3 \%)$ being classified as poor, and in 1990, the incidence of poverty has significantly declined to $15.0 \%$ (Hasan and Hashim, 2001). There was also a sharp decline in the incidence of poverty to $5.5 \%$ in 2000 (Chukwukere and Baharuddin, 2012). The rate of pov- erty in the country has further decreased to 3.8 percent in 2009 (Muhamed and Haron, 2011). However, despite achieving commendable progress in reducing the incidence of poverty in Malaysia during the last few decades, poverty continues to be a major development concern in the country (Othman and Kari, 2008; Nair, 2010). Though all states in the country are recording economic growth, the development gaps between regions, states and rural-urban areas still remain wide (Hasnah and Ahmad, 2009). Particularly, the rate of poverty is still high in the poor states such as Terangganu (24.2\%), Sabah (24.2\%) and Kelantan (10.6\%) (Economic Planning Unit, 2009).

This papers aims to identify the sociodemographic factors that affect the levels of poverty among the households in the state of Kelantan, Malaysia. The paper also focuses on various aspect of household poverty in the state.

\section{MATERIALS AND METH- ODS}

Kelantan is one of the thirteen states in Malaysia. The state is located in the north-eastern corner of the peninsular Malaysia. The state occupies an area of 15,099 square kilometers of land (Department of Statistics, Malaysia, 2011). Total population of the state in 2011 was 1.6 million with average annual population growth rate of $1.6 \%$ (Department of Statistics, Malaysia, 2011). The population of the state comprises several ethnic groups viz. Malay (95\%), Indian (3\%), Chinese $(1.9 \%)$ and others $(0.1 \%)$. Kelantan has a chiefly agrarian economy dominated by rice, rubber and tobacco. Fishing and cottage industries such as handcraft production, weaving and woodcarving are other important economic activities in the state. However, in recent years, tourism, 
especially to offshore islands, has increased in importance.

The study is based on empirical data regarding households' socio-demographic characteristics such as residential status, ethnicity, level of education and housing condition. The data were obtained from the Implementation and Coordination Unit (ICU), Malaysia which collected the information through household survey in the 65 sub-districts under 10 districts in Kelantan in 2010. The surveyed households were divided into four poverty groups: 1) poorest, 2) poor, 3) vulnerable and 4) out of poor. The data were descriptively analyzed utilizing the sociodemographic profiling approach.

\section{FINDINGS}

\subsection{Poverty status of the households based on ethnicity}

Table 1 shows the distribution of household poverty according to ethnicity in $\mathrm{Ke}$ lantan state. The data show a wide variation in the incidence of poverty according to ethnicity of the households. It can be seen that majority $(47.95 \%)$ of the Malays in the state are vulnerable to poverty while only $4.56 \%$ of the households from this ethnic group are the poorest. Nearly one-third $(32.81 \%)$ of the Malays are poor. However, the proportion of poverty free households from this ethnic group is comparatively low (14.68\%). The analyses reveal that nearly two-third $(62.30 \%)$ of the Chinese households are vulnerable to poverty. In contrast, the lowest portion $(2.25 \%)$ of the households from this ethnic group is found to be the poorest. And the proportion of poor and out of poor households is $24.80 \%$ and $10.66 \%$ respectively. Among the Indians, majority is poor $(42.19 \%)$ and vulnerable to poverty $(42.19 \%)$. However, $10.94 \%$ of the
Indian households are out of poverty and only $4.69 \%$ the poorest. It was found that the greatest portion $(70.26 \%)$ of the households from other ethnic groups is vulnerable to poverty. However, the proportions of poorest, poor and out of poor households from this group are 5.38\%, $15.64 \%$ and $8.72 \%$ respectively. The findings highlight that majority of the households from each ethnic group in the state are vulnerable to poverty.

Table 1: Poverty status of the households based on ethnicity

\begin{tabular}{|c|c|c|c|c|c|}
\hline \multirow[t]{2}{*}{ Ethricity } & \multicolumn{4}{|c|}{ Poverty status? } & \multirow[t]{2}{*}{ Total } \\
\hline & Poorest & Poort & Vulnerabler & Out of Poors? & \\
\hline Malayp? & $\begin{array}{c}2111 \\
(4.56 \% \mathrm{o})\end{array}$ & $\begin{array}{c}15191 \\
(32.81 \%)\end{array}$ & $\begin{array}{c}22198+ \\
(47.95 \%)\end{array}$ & $\begin{array}{c}6794 \\
(14.68 \%)\end{array}$ & 46294 \\
\hline Chineser? & $\begin{array}{c}11 \\
(2.25 \%) \mathrm{H}\end{array}$ & $\begin{array}{c}121 \\
(24.80 \%)\end{array}$ & $\begin{array}{c}304 \\
(62.30 \%)\end{array}$ & $\begin{array}{c}524 \\
(10.66 \%)\end{array}$ & 4880 \\
\hline Indian & $\begin{array}{c}3 \\
(4.699 \%)\end{array}$ & $\begin{array}{c}27 \\
(42.19 \%)+\end{array}$ & $\begin{array}{c}274 \\
(42.19 \%)\end{array}$ & $\begin{array}{c}74 \\
(10.94 \%)\end{array}$ & $644^{3}$ \\
\hline Others? & $\begin{array}{c}424 \\
(5.39 \%) \%\end{array}$ & $\begin{array}{c}1224 \\
(15.64 \%)+\end{array}$ & $\begin{array}{c}548+ \\
(70.26 \%)\end{array}$ & $\begin{array}{c}68 \mathrm{H} \\
(8.72 \%) \mathrm{H}\end{array}$ & 7804 \\
\hline
\end{tabular}

\subsection{Poverty status of the households based on locality}

The distribution of household poverty according to locality in Kelantan is presented in table 2. The data demonstrate a significant fluctuation in the incidence of poverty according to residence of the households. The findings reveal that majority of the households are poor and vulnerable to poverty in both urban and rural areas of the state. It was found that the proportion of poorest households is almost similar in both urban $(4.35 \%)$ and rural areas $(4.61 \%)$. However, the proportion of the poor households in urban areas is higher $(39.11 \%)$ than that of rural poor $(30.15 \%)$. In contrast, a significantly greater portion of the rural households $(52.80 \%)$ are vulnerable to poverty compared to the urban households $(35.98 \%)$ of the state. The analysis show that nearly $21 \%$ of the urban households are out of 
poverty, while the proportion of poverty free households in rural areas is comparatively low (12.45\%). The findings indicate that incidence of poverty is higher in rural areas as compared to urban areas of the state.

Table 2: Poverty status of the households based on locality

\begin{tabular}{|c|c|c|c|c|c|}
\hline \multirow[t]{2}{*}{ Locality? } & \multicolumn{4}{|c|}{ Poverty status? } & \multirow[t]{2}{*}{ Totalp } \\
\hline & Poorest & Poor? & Vuluerable: & Out of Poove? & \\
\hline Urban & $\begin{array}{c}530 \\
(4.35 \%) \mathrm{p}\end{array}$ & $\begin{array}{c}767 \% \\
(39.119 \% \mathrm{p}\end{array}$ & $\begin{array}{c}4386 \mathrm{t} \\
(35998 \% \mathrm{pe}\end{array}$ & $\begin{array}{c}25064 \\
(20.56 \%)\end{array}$ & 121894 \\
\hline Rualt & $\begin{array}{c}1637 \\
(4.619 \%)\end{array}$ & $\begin{array}{l}10694 \mathrm{~d} \\
(30.15 \%) \mathrm{p}\end{array}$ & $\begin{array}{c}18727 \mathrm{p} \\
(528.80 \% \mathrm{p})\end{array}$ & $\begin{array}{c}4415 \% \\
(12.45 \%)+\end{array}$ & $35473 P$ \\
\hline
\end{tabular}

3.3 Poverty status of the households according to level of education

Figure 1 shows poverty status of the households based on education level of household's head. It can be seen that majority $(47.48 \%)$ of the household's heads who completed secondary school and above are vulnerable to poverty. In contrast, the lowest portion $(5.66 \%)$ of them is the poorest. However, $36.9 \%$ of the household's heads in this level of education are poor and only $9.96 \%$ out of poverty. The analyses reveal that the greatest portion $(41.03 \%)$ of the household's heads completing secondary school is vulnerable to poverty, followed by the poor $(39.96 \%)$. And the proportions of poorest and out of poor household's heads having secondary education are found to be significantly low $(5.81 \%$ and $13.20 \%$ respectively). It was also found that the percent $(48.27 \%)$ of the household's head who completed primary school and below are vulnerable to poverty. The lowest portion $(4.55 \%)$ of them is the poorest. Nearly one-third $(31.49 \%)$ of the household's heads in this level of education are poor while $15.69 \%$ are out of poverty. The findings show that the greatest portion $(56.83 \%)$ of the household's heads who have no education are vulnerable to poverty. And the propor- tions of poorest, poor and out of poor household's heads having no education are $3.07 \%, 24.91 \%$ and $15.20 \%$ respectively. It can be pointed out that majority of the household's heads in each level of education are vulnerable to poverty.

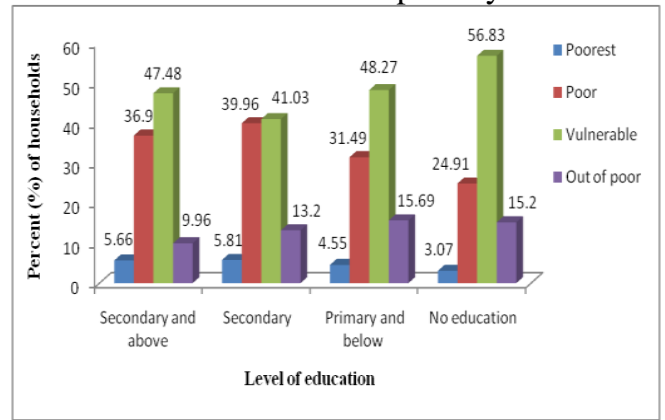

Figure 1: Poverty status of the households according to level of education

\subsection{Poverty status of the households ac-} cording to housing condition

Table 3 describes poverty status of the households based on their housing condition. The data show that majority $(48.46 \%)$ of the households living in a very poor house are classified as vulnerable to poverty. On the other hand, the lowest portion $(4.52 \%)$ of the households residing in a very poor house is treated as the poorest. However, $32.32 \%$ and $14.70 \%$ of the households having a very poor house are categorized as poor and out of poor respectively. It was also found that half $(50.05 \%)$ of the households living in a poor house are treated as vulnerable to poverty, while only $4.48 \%$ are classified as the poorest. And $34.03 \%$ of the households residing in a poor house are reported as poor. However, the proportion of poverty free households who live in a poor house is found to be significantly low (11.44\%). The analyses also show that the greatest portion (45.52\%) of the households who possess a good house is categorized as vulnerable to poverty, followed by the poor $(40.30 \%)$. In contrast, the lowest portion $(6.72 \%)$ of the households having a good 
house is reported as the poorest. And only $7.46 \%$ of the households possessing a good house are classified as out of poverty. The findings suggest that majority of the households living in each type of housing condition are vulnerable to poverty.

Table 3: Poverty status of the households according to housing condition

\begin{tabular}{|c|c|c|c|c|c|}
\hline \multirow{2}{*}{$\begin{array}{l}\text { Housing } \\
\text { condition? }\end{array}$} & \multicolumn{4}{|c|}{ Poventy status? } & \multirow[t]{2}{*}{ Totalp } \\
\hline & Poorest & Poort & Vulherabler & Out of Poor? & \\
\hline \multirow[t]{2}{*}{ Very poor } & 20304 & $14520+$ & 21773 & $6606 \mathrm{t}$ & $449299^{\circ}$ \\
\hline & $(4.52 \%) \%$ & $(32.32 \% \%)=$ & $(48.46 \% \%)^{2}$ & $(14.70 \%) \%$ & \\
\hline \multirow[t]{2}{*}{ Poort } & 454 & $342+$ & $503+$ & 115 & 1005 \\
\hline & $(4.48 \%) \mathrm{O}^{\mathrm{N}}$ & $(34.03 \%)=$ & $(50.05 \% \%)^{2}$ & $(11.44 \%)$ & \\
\hline Goods & $\begin{array}{c}9 \\
(6.72 \%)\end{array}$ & $\begin{array}{c}54 \\
(40,30 \%)\end{array}$ & $\begin{array}{c}61 \\
(45.52 \%)\end{array}$ & $\begin{array}{c}10 \mathrm{H} \\
(7.46 \%)\end{array}$ & 134 \\
\hline $\begin{array}{l}\text { No } \\
\text { infomation }\end{array}$ & $\begin{array}{c}40+4 \\
(4.6490)^{\circ}\end{array}$ & $\begin{array}{c}321 \\
(37.2490)\end{array}$ & $\begin{array}{c}391 \\
(45.36 \% \%\end{array}$ & $\begin{array}{c}1104 \\
(12.76 \% \%)\end{array}$ & 862 \\
\hline
\end{tabular}

\section{CONCLUSION}

The present study analyzes the sociodemographic factors that affect the levels of poverty among the households in $\mathrm{Ke}$ lantan, Malaysia. The analysis of sociodemographic information reveals certain distinct characteristics regarding poverty status of the surveyed households. The study found that majority (on average, $55 \%$ ) of the households from each ethnic group in the state are vulnerable to poverty while the lowest portion (on average, $4 \%$ ) of them are the poorest. It was found that majority of the households are poor and vulnerable to poverty in both urban and rural areas of the state. However, proportion of the poor households in rural areas is higher $(39.11 \%)$ than that of urban poor $(30.15 \%)$. In contrast, a greater portion of the urban households $(52.80 \%)$ are vulnerable to poverty compared to the rural households $(35.98 \%)$ of the state. It was also found that the lowest portion (on average, $4.5 \%$ ) of the household's heads in each education level are the poorest while the greatest portion (on average, $48 \%$ ) of them are vulnerable to poverty.
Analysis also reveals that the proportion of the households living in a very poor or poor house is greater than that of the households who possess a good house. Finally, it can be concluded that from various aspects of socio-demographic characteristics, majority of the households in Kelantan are poor and vulnerable to poverty. Therefore, further research on identification of poverty groups and socio-economic characteristics of such groups is urgently needed for more effective policies and approaches to reduce the rate of poverty in the country.

\section{ACKNOWLEDGEMENT}

This study is supported by the Institute for Environment and Development (LESTARI) and funded by the Post Doctoral Programme under the Centre for Research, Innovation and Instrumental Management (CRIM) (Project Code: UKM-MI-OUP-2012), Universiti Kebangsaan Malaysia (UKM), Malaysia. This study is also supported by the research grant on knowledge transfer on poverty mapping in the East Coast Economic Region (ECER) funded by the Ministry of Higher Education, Malaysia (Project Code: PHI-2012-04) and led by Emeritus Professor Chamhuri Siwar.

\section{REFERENCES}

[1] Chukwukere, O.A. and Baharuddin, A.H., 2012. Risk and poverty in agriculture: Expanding roles for agricultural cooperatives in Malaysia. Geografia, 8 (4): 1-11.

[2] Department of Statistics, Malaysia, 2011. Kelantan at a glance. Department of Statistics, Malaysia, Putrajaya, Malaysia.

[3] Hasan, A.R. and Hashim, S., 2001. Poverty Statistics in Malaysia. Department of Statistics, Malaysia, $\mathrm{Pu}-$ trajaya, Malaysia.

[4] Hasnah, A. and Ahmad, S., 2009. Why Poor Regions Remain Poor? 
Evidence From Malaysia. International Review of Business Research Papers, 5 (2): 161-172.

[5] Ijaiya, G.T., Ijaiya, M.A., Bello, R.A. and Ajayi, M.A., 2011. Economic Growth and Poverty Reduction in Nigeria. International Journal of Business and Social Science, 2 (15): 147-154.

[6] Jiun, C.Y. and Nga, J.L.H., 2011. Economic Growth, Employment Elasticity and Poverty: A Case of Malaysia. Conference proceedings on Persidangan Kebangsaan Ekonomi Malaysia (PERKEM VI), Ekonomi Berpendapatan Tinggi: Transformasi ke Arah Peningkatan Inovasi, Produktiviti dan Kualiti Hidup, 5-7 Jun 2011, Melaka Bandaraya Bersejarah, Malaysia. Pp. 468-481.

[7] Economic Planning Unit, 2009. Ninth Malaysian Plan, 2006-2010. Economic Planning Unit (EPU), Prime Minister's Department, Putrajaya, Malaysia. Pp. 1-547.

[8] Malaysian Quality of Life 2002. The report published by the Economic Planning Unit (EPU), Prime Minister's Department, Putrajaya, Malaysia. Pp. 15.

[9] Mat, S.H.C., Bakar, N.A.A. and Jalil, A.Z.A., 2011. Non Farm Income and Poverty in Kedah, Malaysia. Paper presented in the International Conference on Sociality and Economics Development, Singapore. Pp. 399-403.
[10] Muhamed, K and Haron, S., 2011: Poverty mapping: an effective approach in determining the poor areacase study of Johor. Department of Statistics, Malaysia, Putrajaya, Malaysia.

[11] Nair, S., 2010. Moving forward: Its poverty agenda challenges, dilemmas and options for Malaysia. Paper prepared for CPRC Conference, 810 September 2010.

[12] Othman, A. and Kari, F., 2008. Enhancing co-operatives movement to achieve Malaysia's development goals. Paper presented at the ICA Research Conference, October 2008, riva del Gardea,Trento Italy.

[13] Roslan, A.H., 2004. Measuring Poverty in Malaysia: Applications of Distributive-Sensitive Poverty Indices. Malaysian Management Journal, 8 (1): 25-37.

[14] United Nations, 1995. The Report of the World Summit for Social Development and Programme of Action. 16-12 March 2005, Copenhagen, Denmark.

[15] World Bank, 1990. Poverty. World Development Report 1990. New York; Oxford University Press.

[16] World Bank, 2005. Overview: Understanding, measuring and overcoming poverty. Available at: http://www.colorado.edu/philosophy /healthwood/pdf/worldbank.pdf. 